\title{
Histological Changes of Liver Tissue and Serobiochemical Relation in Does with Pregnancy Ketosis
}

\author{
Azmi $\mathrm{AFM}^{1}$, Ghani AAA ${ }^{1}$, Saadan $\mathrm{AS}^{1}$, Mokrish A ${ }^{1}$, Lai KS $^{2}$, Zamri-Saad M${ }^{1}$, Zuki AB ${ }^{1}$, Hassim $\mathrm{HA}^{1}$ \\ ${ }^{I}$ Faculty of Veterinary Medicine, Universiti Putra Malaysia, Serdang 43400, Selangor, Malaysia \\ ${ }^{2}$ Faculty of Biotechnology and Biomolecular Sciences, Universiti Putra Malaysia, Serdang 43400, Selangor, Malaysia \\ E-mail: haslizaabu@upm.edu.my
}

(received 04-04-2016; revised 10-06-2016; accepted 20-06-2016)

\begin{abstract}
ABSTRAK
Azmi AFM, Ghani AAA, Saadan AS, Mokrish A, Lai KS, Zamri-Saad M, Zuki AB, Hassim HA. 2016. Perubahan histologi jaringan hati dan hubungan serum biokimia pada kambing yang mengalami kebuntingan ketosis. JITV 21(2): 96-100. DOI: http://dx.doi.org/10.14334/jitv.v21i2.1357

Perubahan histologi hati kambing yang mengalami kebuntingan ketosis dikarakterisasi pada penelitian ini. Dua puluh kambing bunting pada hari ke-80 digunakan pada percobaan ini. Sepuluh kambing bunting diberi pakan rumput (Napier) dan konsentrat bersama air secara ad libitum dikategorikan sebagai kambing bunting yang sehat dan 10 kambing lainnya yang menunjukkan gejala-gejala klinik dan subklinik ketosis dikategorikan sebagai kambing bunting tidak sehat. Biopsi hati dilakukan saat gejala klinik muncul. Beta-Hydroxybutyrate (BHBA), asam lemak bebas, dan gula ditentukan dosisnya. Persiapan histologi menunjukkan persamaan insidensi dan intensitas steatosis hati ringan bersama vakuolasi seluler yang lebih rendah di dalam hepatosit kambing bunting yang sehat. Hampir semua kambing bunting yang menderita ketosis $(\mathrm{n}=8 / 10)$ mempunyai jumlah kadar tetesan lipid yang besar di dalam setiap hepatosit di semua asinus hati bersama kadar selular vakuolasi yang tinggi, serta berhubungan dengan peningkatan kadar BHBA dan asam lemak bebas saat terjadi penurunan kadar gula dalam darah.
\end{abstract}

Kata Kunci: Asam Lemak Bebas, Beta-Hydroxybutyrate, Kambing, Biopsi Hati, Kebuntingan Ketosis

\section{ABSTRACT}

Azmi AFM, Ghani AAA, Saadan AS, Mokrish A, Lai KS, Zamri-Saad M, Zuki AB, Hassim HA. 2016. Histological changes of liver tissue and serobiochemical relation in does with pregnancy ketosis. JITV 21(2): 96-100. DOI: http://dx.doi.org/10.14334/jitv.v21i2.1357

Histological changes of liver in does with pregnancy ketosis were characterized. Twenty pregnant does at day 80 of pregnancy were used for this experiment. A total of 10 does were fed by grass (Napier) and goat concentrate with water ad libitum. Those 10 goats considered as healthy pregnant goat, and another 10 goats showing clinical and subclinical signs of ketosis considered as unhealthy pregnant does. Liver biopsies were performed when clinical signs appeared. BetaHydroxybutyrate (BHBA), free fatty acid (FFA), and glucose were dosed. Histological preparation revealed similar incidence and intensity of mild liver steatosis with lower cellular vacuolation in hepatocyte presence in healthy late pregnant does. Almost all of the pregnant does with ketosis state $(n=8 / 10)$ had large amount of small lipid droplets in almost every hepatocyte over the whole liver acinus with higher number of cellular vacuolation, and related with higher BHBA and FFA levels while low in glucose level.

Key Words: Beta-Hydroxybutyrate, Does, Free Fatty Acid, Liver Biopsies, Pregnancy Ketosis

\section{INTRODUCTION}

Recently, there was a sharp increase in goat milk and meat demand in Malaysia, particularly in the last three decades due to rapid economic and population growth, with the resultant effects of urbanization, income growth and change of consumer preference (Bisant 2010). Nevertheless, scientifically based on goat farms and industry information in Malaysia, supply is extremely limited to meet the sudden surge of goat milk and meat demand. Urgent issues faced by goat farmers were the improper rearing management, feed and feeding, diseases and marketing (Jamaludin et al. 2012). Pregnancy ketosis has been recognized as one of the common metabolic diseases influencing goat meat and milk production (Bani-Ismail et al. 2009). Pregnancy ketosis commonly occured in goat or sheep during the late stage of gestation with a low morbidity rate $(2-5 \%)$ but a high mortality rate $(80 \%)$ (Brounts et al. 2004; Zamir et al. 2009; Brozos et al. 2011). The main cause of pregnancy ketosis in goats was a disturbance of carbohydrate metabolism due to high demand for glucose by the developing fetuses in the last trismester of pregnancy, resulting negative energy balance 
(Schlumbohm \& Harmeyer 2004). As a fetal requirement of glucose exceeding dietary energy intake, increase in lipolysis led to an augmented synthesis of ketone bodies (BHBA) to maintain metabolic homeostasis (Pethick \& Lindsay 1982; Sargison et al. 1994). The disturbance of carbohydrate metabolism generates high plasma free fatty acids and ketone bodies level. It was suggested that fatty liver due to lipolysis interferes with hepatic gluconeogenic capacity, thus ketosis and fatty liver disease would play a central role in pregnancy ketosis (Herdt 2000).

Histopathological reports related to the disease are usually referred to data obtained from liver biopsy or during post mortem examination. Many workers claimed that during ketosis, this condition occured to some tissues of animal i.e. cerebral and cerebellar neuronal necrosis and vacuolation, early structural maturity of placenta, and liver steatosis (Snook 1939; Mitchell \& Stratford 1987; Marteniuk \& Herdt 1988; Jeffrey \& Higgins 1992; Andrews 1997). Although being a rather commonly studied disease, there are no previous researchs which access evolution of histological changes of liver tissue during pregnancy ketosis in relation to serobiochemical changes.

The aim of this work was to assess and characterize evolution of histological changes of liver in does induced to pregnancy ketosis by puncture biopsy method. It also studied relation of these changes with glucose, BHBA and free fatty acid levels to consider then as possible prognostic indicator of hepatic damage in this disease and determination severity of pregnancy ketosis in does.

\section{MATERIALS AND METHODS}

\section{Animal selection}

Twenty crossed Boer goats aged between 1 to 3 years old are studied from December 2014 to December 2015. A total of 10 clinically healthy does were used as the control group while another 10 does with clinical signs of ketosis considered as unhealthy animal. All the stages of pregnancy were confirmed by ulrasonography at day 80. All does carried singleton pregnancy. Sampling procedure was approved by Ethical Committee for Animal Experiments, Universiti Putra Malaysia.

\section{History and selection of cases}

Examined goats were raised in small-scale flocks in rural areas. Those pregnant goats were fed on natural grasses (Napier), concentrate with supplementation of roughage and running water ad libitum. They were diagnosed with suspected pregnancy ketosis via clinical histories and through physical examination.

\section{Biochemical examination}

Blood samples were collected from all does under experimentation; the first sample collected in plain Vacutainer tubes and used for serobiochemical examination (eg: glucose) by sending it to clinical pathology lab, UPM. Next, sample was collected in EDTA tubes and plasma was separated using centrifuge under 3000x rpm. All those plasma were stored at $20^{\circ} \mathrm{C}$ until further utilization. Beta-hydroxubutyrate (BHBA) and free fatty acids (FFA) were examined using plasma sample. BHBA and FFA were examined using spectrophotometric following standard methods using commercial ELISA kits (CAYMAN, USA).

\section{Histopathological examination}

Samples were collected from healthy goats as control and goats suffering severe ketosis. Liver samples were collected using liver biopsy and local anesthesia was given before the sample collection. All liver specimens obtained by biopsy were processed and stained using hematoxylin and eosin. The present of fat droplet in liver cell and severity of cellular vacuolar degeneration was evaluated at 20 times and 40 times of power magnification and scored according to Stockhaus et al. (2004): 1 = small amounts in a minority of cells, 2 $=$ variable amounts in a majority of cells, and $3=$ large amounts in almost every hepatocyte.

\section{Statistical analysis}

All the analysis were done with SPSS version 20.0 software and data represent as a mean were considered significantly different when $\mathrm{P}<0.05$.

\section{RESULTS AND DISCUSSION}

Liver biopsy is the most practical method for fatty liver diagnosis. Transthoracic needle biopsies used for safely taken and easily through the tenth interescostal space at level of the greater trochanter. Samples of biopsy taken should be evaluated qualitatively for histological means using grading system. Figure 1 shows the healthy liver of pregnant does with absence of fat droplet and presence of steatotic changes with mild condition. This study was inline with Rook (2000) who reported that healthy pregnant showed a largely unchanged during the experiment and mild steatotic changes recorded in those does seemed to be a normal feature during late pregnancy. Figure 2 shows the goats liver under subclinical ketosis which fatty acid accumulation was presence in every single of liver cell. At this stage, the majority of affected does was poorly extended degeneration. 


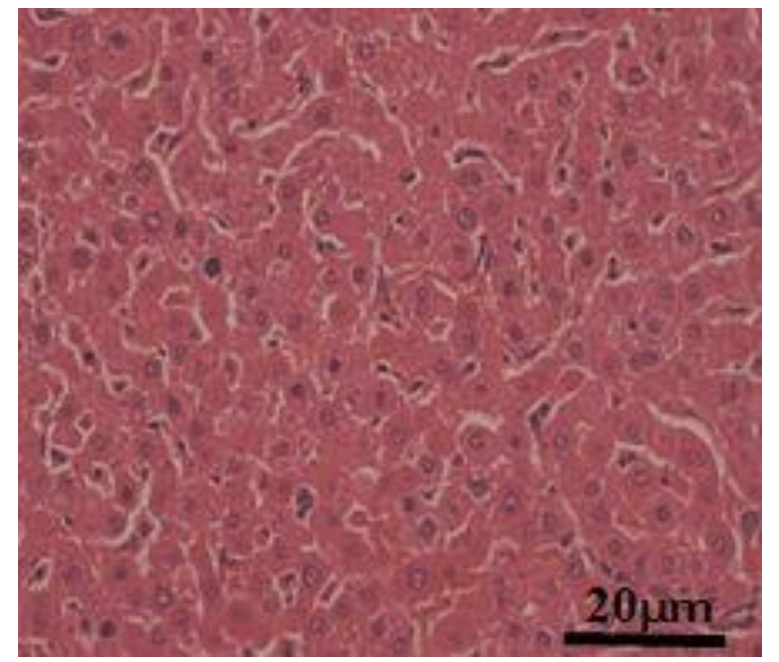

Figure 1. Healthy goat liver condition. Photomicrograph of healthy liver with absence of lipid droplets in almost every hepatocyte. Healthy goats liver under 40x magnification. Scale bar $=20 \mu \mathrm{m}$.

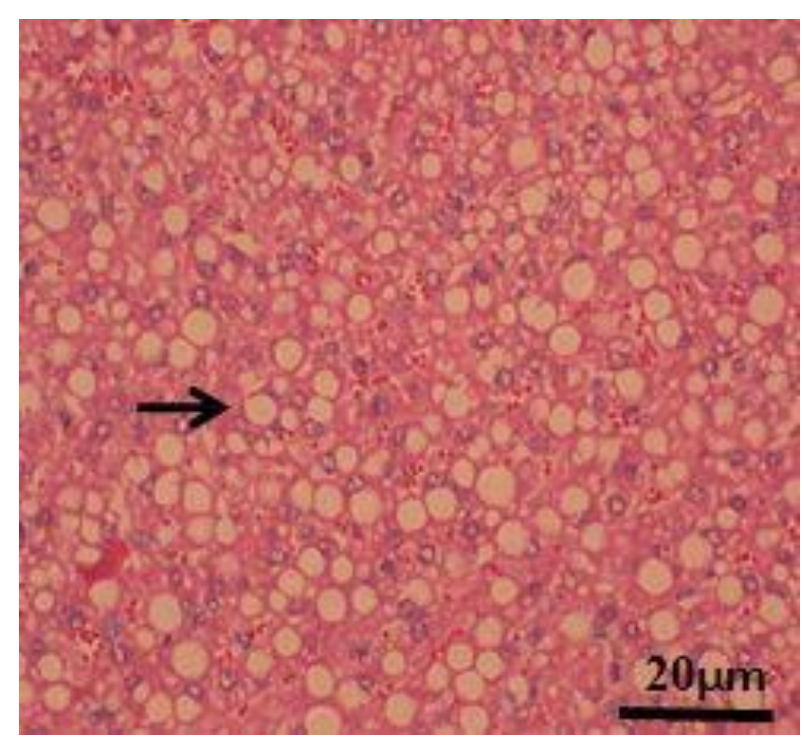

Figure 2. Goats liver under subclinical ketosis. Severe liver contains large amount of lipid droplets in almost every hepatocyte. Fatty liver pregnancy ketosis goats under 40x magnification. Scale bar $=20 \mu \mathrm{m}$. Arrows show the presence droplet of fat inside hepatocyte cell. Photomicrograph of liver of goat with diffuse hepatic lipidosis showing macrovacuales vacuoles pushing the nucleus to one side which signet ring appearance.

This description and corresponding illustration given by Jaeschke et al. (2002) fit with this study stated microvesicular degeneration caused by acute starvation due to fatty acid accumulation. During ketosis, hepatic degeneration during late pregnancy in ketosis doe was a microvesicular type. Microvesicular types of steatosis has been described and corresponding illustration given by Snook (1939) and were obtained from a slaughtered ewe that comatose due to pregnancy ketosis.

Histological investigation also demonstrated liver degeneration incidence and severity in both groups. Healthy goats in this experiment remained largely and unchanged on cellular vacuolation with score $1.22 \pm 0.44$ (which score around 1 and 2) and mild steatotic changes observed. According to Rook (2000), mild steatotic changes observed during the late pregnancy considered as normal. However, a ketosis goat in this experiment showed higher liver degeneration and cellular vacuolation which grade of cellular vacuolation around $2.89 \pm 0.33$ (which score around 2 and 3). Higher cellular vacuolation during pregnancy ketosis also supported by Cal et al. (2009) which enhanced lipidic mobilization in starved animals would have caused a higher incidence of vacuolation and was significantly enhanced at the end of the starving period. All samples with degeneration diagnosis of both groups corresponded to the cellular vacuolation (Table 1), and alterations such as steatohepatitis or necrosis were not detected.

Table 1. Number of goats with and without liver degeneration corresponding degree of cellular vacuolation

\begin{tabular}{lcc}
\hline \hline Groups & $\begin{array}{c}\text { Number of } \\
\text { animal (n) }\end{array}$ & $\begin{array}{c}\text { Cellular } \\
\text { vacuolation }\end{array}$ \\
\hline Healthy goats & 10 & $1.22 \pm 0.44$ \\
$\begin{array}{l}\text { Subclinical pregnancy } \\
\text { ketosis goats }\end{array}$ & 10 & $2.89 \pm 0.33$ \\
\hline
\end{tabular}

$* \mathrm{P}<0.05$

In this study, serum biochemical profiles in does were characterized as subclinical pregnancy ketosis. Depression and teeth grindings were the first signs observed in both mild and advance pregnancy ketosis goats. This study indicated that the goat with subclinical pregnancy ketosis, as determined by ketonemia, were more likely to have hypoglycaemia and azotemia compared to non ketotic pregnant goats during the third trimester pregnancy. Laboratory findings showed the presence of high number of BHBA and FFA of clinically affected goats in the plasma which $1.37 \pm 0.47$ $\mathrm{mmol} / \mathrm{L}$ and $0.98 \pm 0.22 \mathrm{mmol} / \mathrm{L}$, respectively (Table 2). The increase of FFA concentration in plasma of affected goats could be attributed to the increase of mobilization of fatty acids from adipose tissue in response to a requirement for endogenous substrate for energy production during pregnancy (Noble et al. 1971). Indeed, elevation level of FFA due to ketosis inside plasma reflected the formation of fatty liver in pregnant does. It also suggested that plasma FFA would be the most useful index of degree of under 
nourishment in pregnant does (Russel et al. 1976). Thus, increase of FFA levels during ketosis state reflected the elevation of BHBA level which was $1.37 \pm 0.47 \mathrm{mmol} / \mathrm{L}$. Previous study reported that goat having range $\mathrm{BHBA}$ around 0.8 to $1.6 \mathrm{mmol} / \mathrm{L}$ (Sadjadian et al. 2013), $>0.86 \mathrm{mmol} / \mathrm{L}$ (Bani-Ismail et al. 2009), >1.1 mmol/L (Brozos et al. 2011) were considered as a subclinical pregnancy ketosis. Sadjadian et al. (2013) also reported that an excessive negative energy balance prepartum could be identified by presence of hyperketonemia. Elevation of BHBA level also was able to inhibit hepatic gluconeogenesis, and thus further increase maternal hypocglycaemina (Schlumbohm \& Harmeyer 2004). The result also demonstrated that glucose level of ketotic goats $1.13 \pm 0.48 \mathrm{mmol} / \mathrm{L}$ was lower than healthy goat $2.88 \pm 0.33 \mathrm{mmol} / \mathrm{L}$ (Table 2). Glucose is the main sources for supplying energy in the body. Glucose level shows relation to the animal energy status which its values was negatively related with a negative energy balance. These results showed an increase in mobilization of glucose as well as free fatty acids to be used in thermogenic process (Terashima et al. 1982). In addition, data collected could be used by veterinarians to aid in clinical investigation of herds and individual goats in late pregnancy, and help in the understanding of histologic and pathophysiologic changes occured in this species.

Table 2. Serum metabolic constituents in does in late pregnancy, with and without (healthy) subclinical pregnancy ketosis

\begin{tabular}{lcc}
\hline \hline Constituents & $\begin{array}{c}\text { Subclinical } \\
\text { ketosis }(\mathrm{n}=10)\end{array}$ & $\begin{array}{c}\text { Healthy goats } \\
(\mathrm{n}=10)\end{array}$ \\
\hline Glucose $(\mathrm{mmol} / \mathrm{L})$ & $1.13 \pm 0.48$ & $2.88 \pm 0.33$ \\
$\begin{array}{l}\text { Beta Hydroxybutyrate } \\
(\mathrm{mmol} / \mathrm{L})\end{array}$ & $1.37 \pm 0.47$ & $0.13 \pm 0.06$ \\
$\begin{array}{l}\text { Free Fatty Acids } \\
(\mathrm{mmol} / \mathrm{L})\end{array}$ & $0.98 \pm 0.22$ & $0.18 \pm 0.08$ \\
\hline
\end{tabular}

$* \mathrm{P}<0.05$

\section{CONCLUSION}

It was concluded that a pregnancy ketosis during late pregnancy in does could produce fatty liver with higher cellular vacuolation. Severity of liver damage and presence of fat droplet was found to be associated with higher number of FFA and BHBA and lower values of glucose levels in the blood plasma.

\section{ACKNOWLEDGEMENTS}

Authors would like to thank farmers in all Ladang Angkat Universiti Putra Malaysia (UPM) for allowing us to examine their herds and collecting samples. We would also like to thank staff of Universiti Veterinary Hospital (UVH) for facilitating laboratory evaluation of the plasma samples in their laboratories. This study also was financially supported by the FRGS Grant and Ministry of Higher Education, Malaysia.

\section{REFERENCES}

Andrews A. 1997. Pregnancy toxaemia in the ewe. In Pract. 19:306-314.

Bani-Ismail ZA, Al-Majali AM, Amireh F, Al-Rawashdeh OF. 2009. Metabolic profiles in goat do in late pregnancy with and without subclinical pregnancy toxemia. Vet Clin Pathol. 37:434-437.

Bisant K. 2010. Consumer preference for goat meat in Malaysia: Market opportunities and potential. J Agribus Mark. 3:40-55.

Brounts S, Hawkins J, Baird AN, Glickman L. 2004. Outcome and subsequent fertility of sheep and goats undergoing caesarean section because of dystocia: 110 cases (19812001). J Am Vet Med Assoc. 224:275-279.

Brozos C, Mavrogianni VS, Fthenakis GC. 2011. Treatment and control of peri-parturient metabolic diseases: Pregnancy toxemia, hypocalcemia, hypomagnesemia. Vet Clin North Am Food Anim Pr. 27:105-113.

Cal L, Borteiro C, Benech A, Rodas E, Abreu MN, Cruz JR, Montana G. 2009. Histological changes of the liver and metabolic correlates in ewes with pregnancy toxemia. Arq Bras Med Vet Zootech. 61:306-312.

Herdt TH. 2000. Ruminant adaptation to negative energy balance. Vet Clin North Am Food Anim Pr. 16:215-230.

Jaeschke H, Gores GJ, Cederbaum AI. 2002. Mechanisms of hepatotoxicity. Toxicol Sci. 65:166-176.

Jamaludin AA, Idris K, Roslaini R. 2012. Challenges facing dairy goat farmers in Malaysia. In: Abdullah R, Omar MA, Makkar H, Otte J, Rajion MA, Alimon AR, Boo LJ, Kam HA, Li CW, editors. Proceeding First Asia Dairy Goat Conference. Kuala Lumpur (Malays): Universiti Putra Malaysia and The Food and Agricultural Organization of the United Nations. p. 1113.

Jeffrey M, Higgins RJ. 1992. Brain lesions of naturally occurring pregnancy toxaemia of sheep. Vet Pathol. 29:301-307. 
Marteniuk JV, Herdt TH. 1988. Pregnancy toxemia and Ketosis of ewes and does. Vet Clin North Am Food Anim Pr. 4:307-315.

Mitchell GM, Stratford BF. 1987. The morphology of the ovine placenta in pregnancy toxaemia. Aust Vet J. 64:221-223.

Noble RC, Steel W, Moore JH. 1971. The plasma lipids of the ewe during pregnancy and lactation. Res Vet Sci. 12:4753.

Pethick DW, Lindsay DB. 1982. Metabolism of ketone bodies in pregnant sheep. Br J Nutr. 48:549-563.

Rook JS. 2000. Pregnancy toxemia of ewes, does, and beef cows. Vet Clin North Am Food Anim Pr. 16:293-317.

Russel AJF, Donery JN, Reid RL. 1976. The use of biochemical parameters in controlling nutritional state in pregnant ewes and the effect of undernourishment during pregnancy on lamb birth-weight. J Agric Sci Camb. 68:359.

Sadjadian R, Seifi HA, Mohri M, Naseian AA, Farzaneh N. 2013. Variations of energy biochemical metabolites in periparturient dairy Saanen goats. Comp Clin Pathol. 22:449-456.
Sargison ND, Scott PR, Penny CD, Pirie RS, Kelly JM. 1994. Plasma enzmes and metabolites as potential prognostic indices of ovine pregnancy toxaemia a preliminary study. Br Vet J. 150:271

Schlumbohm C, Harmeyer J. 2004. Hyperketonemia impairs glucose metabolism in pregnant ewes. J Dairy Sci. $87: 350-358$

Snook LC. 1939. Fatty infiltration of the liver in pregnant ewes. J Physiol. 97:238-249.

Stockhaus C, Van Den Ingh T, Rothuizen J. 2004. A multistep approach in the cytologic evaluation of liver biopsy samples of dogs with hepatic diseases. Vet Pathol. 41:461-470.

Terashima Y, Tucker RE, Deets LE, Degregorio RM, Muntifering RB, Mitchell CE. 1982. Plasma magnesium levels as influenced by cold exposure in fed or fasted sheep. J Nutr. 112:1914-1920.

Zamir S, Rozov A, Gootwine E. 2009. Treatment of pregnancy toxaemia in sheep with flunixin meglumine. Vet Rec. 165:265-266. 